\title{
Yerel Yönetişim Bağlamında Avrupa Konseyi "12 Yıldızlı Şehir” Uygulaması ve Türkiye Yerel Yönetimleri
}

\section{The Council of Europe 12 Star City Implementation in the Context of Local Governance and Local Governments of Turkey}

\author{
Dr. Onur Kemal YILMAZ iD 1
}

\begin{abstract}
Öz
Avrupa Konseyi yerel yönetişimin geliştirilmesi için çalışmalar ortaya koymaktadır. Bu kapsamda konseye üye ülkelerin yerel yönetimlerini “Avrupa Yerel Demokrasi Haftası” adı altında, yerel yönetişimi geliştirici etkinlikler düzenlemeleri için teşvik etmektedir. Bu etkinlik çerçevesinde faaliyet gerçekleştiren yerel yönetimlere "12 Yıldızlı Şehir" statüsü verilmektedir. Bu statü yıllık olarak verilmektedir ve statünün tekrar alınması için her yıl aynı etkinliğe tekrar katılmak gerekmektedir. Konuyla ilgili olarak bu çalışma kapsamında Türkiye'den Avrupa Yerel Demokrasi Haftası etkinliklerine katılım sağlayan ve 12 Yıldızlı Şehir statüsü alan yerel yönetimler tespit edilmeye çalışılmıştır. Ayrıca ilgili yerel yönetimlerin bu etkinlik kapsamında yaptıkları çalışmalar da tespit edilmeye çalışılmıştır. Yapılan inceleme sırasında Türkiye'den Avrupa Yerel Demokrasi Haftası etkinliklerine katılan ve 12 Yıldızlı Şehir statüsü kazanan belediyeler olduğu görülmüştür. Bunun yanında söz konusu statüyü ilk defa kazanmak için Türkiye'den farklı belediyelerin çalışmalar yaptıkları da dikkat çekmektedir. Fakat il özel idarelerinin, köy idarelerinin, STK'ların ve diğer yerel yönetişim aktörlerinin bu etkinliğe katılım sağlamadıkları görülmektedir.
\end{abstract}

Anahtar Kelimeler: 12 Yıldızlı şehir, Avrupa Yerel Demokrasi Haftası, yerel yönetişim, küresel yönetişim, ulusal yönetişim

Makale Türü: Araştırma

\begin{abstract}
The Council of Europe is working to improve local governance. In this context, the Council encourages the local governments of the member countries to organize activities to promote local governance under the name of European Local Democracy Week. 12-Star City status is given to local authorities which participate this activity. This status is given annually and it is necessary to rejoin the same event every year in order to get the status again. Within the scope of this study, local governments from Turkey which participate to European Local Democracy Week and gets 12 Star City status have been tried to determined. In addition, the activities of the related local governments within the scope of this week have been tried to be determined. During the review it is determined that, there are municipalities from Turkey which participate to European Local Democracy Week and gets 12 Star City status. Besides it draws attention that, different municipalities from Turkey participate to week to win the status for the first time. However, it is determined that special provincial administrations, village administrations, NGOs and other local governance actors are not participating to this event.
\end{abstract}

Keywords: 12 Stars city, European Local Democracy Week, local governance, global governance, national governance

Paper Type: Research

${ }^{1}$ Bandırma Onyedi Eylül Üniversitesi, Yerel Yönetimler Programı, yilmazonurkemal@gmail.com.

Atıf için (to cite): Yılmaz, O.K. (2019). Yerel yönetişim bağlamında Avrupa Konseyi "12 Yıldızlı Şehir" uygulaması ve Türkiye yerel yönetimleri. Afyon Kocatepe Üniversitesi Sosyal Bilimler Dergisi, 22(1), 214-232. 


\section{Giriş}

Yönetişim kavramı akademik çevrelerde, resmi kurumlarda, kamu idarelerinde, sivil toplum kuruluşlarında ve diğer organizasyonlarda hem ulusal hem de uluslararası seviyede tartışılan kavramlardan birisi haline gelmiştir. Yönetişimin, insanların temel hizmet ve demokratik haklarını elde etmeleri için önemli kazanımlardan bir tanesi olduğu genel kabul görmüş durumdadır. Dolayısıyla yönetişimin daha çok geliştirilmesine yönelik çalışmalar ulus altı ve ulus üstü ölçeklerde ortaya konulmaktadır. Son yıllarda özellikle yerel yönetişim konusunda da önemli çalışmalar ortaya konulmaktadır. İnsanların yerel düzeyde aldıkları hizmetlerde daha çok katılımcılık sağlamaları ve söz hakkına sahip olmaları önemli bir çalışma alanı olarak görülmektedir. Özellikle gelişmiş ve gelişmekte olan ülkelerde bu yönde somut uygulamaların sayıları her geçen gün artmaktadır. Avrupa Konseyi de bu yönde yerel yönetişimi geliştirici etkinlikler ortaya koymaktadır. Avrupa Yerel Demokrasi Haftası bunlardan birisidir ve bu etkinliğe katılım gösteren yerel yönetimlere 12 Yıldızlı Şehir statüsü verilmektedir. Avrupa Konseyi'nin 47 üye ülkesi bulunmaktadır ve bunlardan birisi de Türkiye'dir. Dolayısıyla bu çalışma ile Avrupa Yerel Demokrasi Haftası'na Türkiye'den yerel yönetimlerin katılımları tespit edilmeye çalışılmıştır. Çalışma içerisinde yanıt aranan sorular şu şekildedir;

1- Avrupa Konseyi tarafından düzenlenen Avrupa Yerel Demokrasi Haftası'na Türkiye'den yerel yönetimler katılmakta mıdır?

2- Avrupa Yerel Demokrasi Haftası'na Türkiye'den hangi yerel yönetimler katılmaktadır?

3- Avrupa Yerel Demokrasi Haftası'na Türkiye'den katılan yerel yönetimlerin konuyla ilgili yaptıkları çalışmalar nelerdir?

4- 12 Yıldızlı Şehir statüsüne sahip olmak için sağlanması gereken kriterler nelerdir?

5- Avrupa Konseyi tarafından verilen 12 Yıldızlı Şehir statüsüne Türkiye'den hangi yerel yönetimler sahiptir?

6- Avrupa Yerel Demokrasi Haftası'na katılan ülkelerin yerel yönetimleri içerisinde, Türkiye'den yerel yönetimlerin katılım oranı nedir?

\section{Yöntem}

Çalışma kapsamındaki sorulara yanıt aranırken belgesel tarama yönteminden istifade edilmiştir. Karasar'ın belirttiğine göre belgesel tarama; var olan kayıt ve belgeleri inceleyerek veri toplamaktır. Kaynakları bulma, okuma, not alma ve değerlendirme belgesel taramanın içeriğini oluşturmaktadır (Karasar, 2012, s. 183). Dolayısıyla çalışma kapsamında doğrudan Avrupa Konseyi'nin internet siteleri incelenmiştir ve harici kaynaklara başvurulmasına gerek görülmemiştir. Bunun sebebi ihtiyaç duyulan bilgilerin en net olarak Avrupa Konseyi'nin, Avrupa Konseyi Yerel ve Bölgesel Yönetimler Kongresi'nin ve Avrupa Yerel Demokrasi Haftası etkinliğinin internet sitelerinde bulunmasıdır. Ayrıca bu konuyla ilgili yabancı literatürde kısıtlı çalışma yapıldığı, Türkçe literatürde ise henüz çalışma yapılmadığı görülmüştür. Dolayısıyla Türkçe literatüre Avrupa Yerel Demokrasi Haftası ile ilgili katk1 yapmak da bu çalışmanın hedefleri arasında yer almıştır.

\section{Yönetişim Kavramı}

Yönetişim kavramının 1980'li yıllardan sonra yaygın olarak kullanıldığı görülmektedir. $\mathrm{Bu}$ tarihten sonra Birleşmiş Milletler (UN), Dünya Bankası (WB), Ekonomik Kalkınma ve İşbirliği Örgütü (OECD), Uluslararası Para Fonu (IMF) gibi uluslararası kuruluşlar yayınladıkları çeşitli raporlarda yönetişim kavramını kullanmışlardır. Fakat yönetişim kavramını farklı organizasyonlar hukuk, siyaset, kamu idaresi ve işletme gibi çeşitli alanlarda ortaya koyduklarından, bu kavramın tanımına dair tek bir açıklamadan söz edilememektedir. Konuya kamu yönetimi açısından bakılacak olursa, yönetişim ile kastedilenin, klasik kamu yönetimi 
anlayışının dışına çıkılarak, devletin tek taraflı yönetme gücünü diğer aktörlerle paylaşması olduğu söylenebilir (Sobac1, 2007, s. 220). Birleşmiş Milletler raporuna göre yönetişim kavramı yeni bir kavram değildir ve insanlık tarihi kadar eski bir geçmişe sahiptir. Aynı rapora göre yönetişim kavramının temas ettiği temel nokta karar alma süreçlerini kapsamaktadır (United Nations, 2009, s. 1). Yönetişim kavramının yönetim kavramıyla birlikte ele alınması konunun daha net anlaşılmasını sağlayabilir. Yönetim kavramında karar alma doğrudan yöneticiler tarafından sağlanırken, yönetişimde birlikte karar almaya geçiş söz konusudur (Işık, 2010, s. 40). Dolayısıyla yönetişimi en sade olarak; tek taraflı yönetim anlayışından ziyade, sonuçlardan etkilenenlerin karar alma süreçlerine katılımı olarak tanımlamak mümkündür. Bunun yanında yönetişim kavramının içeriği oldukça geniştir. Türkiye Cumhuriyeti Dokuzuncu Kalkınma Planı, "Kamuda İyi Yönetişim" başlıklı Özel İhtisas Komisyonu Raporu’na göre yönetişim: hukukun üstünlüğ̈̈, demokrasi ve insan haklarına önem veren; faaliyetlerde katılımcıllı̆g, etkinliği ve etkililiği tesis eden; denetim mekanizması oluşturan; yerinden yönetime vurgu yapan; açıklık, saydamlık ve hesap verebilirliği mümkün kılan; liyakati ve etiği öne çıkartan; sivil toplumu merkeze alan; sivil toplum kuruluşlarının önünü açan; bağımsız yarg1 düzenini geliştiren; teknoloji ile uyumlu ekonomik ve siyasi düzendir (Kamuda İyi Yönetişim, 2007, s. 5).

\section{1. İyi Yönetişim Prensipleri}

Yönetişim kavramının dünyada üst seviyelerde tartışıldığı görülmektedir. Küresel ölçekte faaliyet gösteren resmi ve gayri resmi organizasyonlar, özellikle kamu idaresi alanında toplumların kendilerini ilgilendiren meselelerde söz haklarının olması konusunda görüşler ortaya koymaktadırlar. Avrupa Birliği’nin politikalarını belirleyen ve şekillendiren Avrupa Komisyonu veya tam adiyla Avrupa Toplulukları Komisyonu (Commission Of The European Communities) da bu alanda önemli bir çalışma ortaya koymuştur. Avrupa Yönetişimi: Bir Beyaz Kitap (European Governance: a White Paper) isimli bu çalışmada yönetişim kavramının önemi ve $\mathrm{AB}$ bünyesinde neden yönetişim kavramının geliştirilmesi gerektiği açıklanırken, $\mathrm{AB}$ bünyesinde iyi bir yönetişim anlayışının sahip olması gereken temel ilkeler de açılanmaktadır. $\mathrm{Bu}$ metne göre $\mathrm{AB}$ bünyesinde tesis edilmesi gereken iyi yönetişimin ilkeleri şunlardır (Avrupa Topluluklar1, 2001, s. 10);

- Açıklık: Tüm kurumların açık bir tarzla çalışmasını kastetmektedir. Avrupa Birliği’ne üye ülkelerin ve kurumların birbirleri ile aktif iletişim içinde olmaları ve çalışmalarında halkın anlayabileceği seviyede anlaşılabilir bir dil kullanmaları önerilmektedir. Böylece kurumlara olan güvenin artacağı dile getirilmektedir.

- Katılım: AB politikalarının etkin bir şekilde ortaya konulabilmesi için, karar alma süreçlerinin tamamında katılımcılığın en önemli bileşen olduğu vurgulanmaktadır. Böylece kurumlara ve bu kurumlarda alınan kararlara olan inancın artacağına inanılmaktadır.

- Hesap Verebilirlik: AB bünyesinde yasama ve yürütme faaliyetlerinin açık bir şekilde gerçekleştirilmesini ifade etmektedir. Bu kapsamda $\mathrm{AB}$ bünyesindeki tüm kurumların faaliyetleriyle ilgili açı olmaları ve yaptıklarının sorumluluklarını almaları savunulmaktadır.

- Etkinlik: AB bünyesinde ortaya konulan politikaların etkin ve zamanında ortaya konulmalarını tanımlamaktadır. Bu politikaların geçmiş tecrübelerden beslenmesini ve açık hedeflerle ortaya konulmalarını gerekli görmektedir.

- Uyum: Ortaya konulan politikaların ve bunlara bağlı faaliyetlerin birbirleri ile uyumlu olmasını açıklamaktadır. Bu görüşe göre özellikle AB'nin büyümesi, sınırlarının genişlemesi ve bünyesindeki çeşitliliğin artması uyum konusuna olan önemi daha fazla arttırmaktadır. 
$\mathrm{Bu}$ beş yönetişim uygulaması kendi başlarına önemli alanlar olsalar da birbiri ile bütün halinde ortaya konulması gereken bileşenler olarak görülmektedirler. Böylece, Avrupa topluluğuna üye ülkelerde ulusal, bölgesel ve yerel ölçekte daha demokratik yönetişim sistemlerinin kurulmasının mümkün olacağı düşünülmektedir.

\subsection{Kamu Yönetiminde Yönetişimin Yeri}

Yönetişim, kamusal ölçekte yönetim sistemlerinin daha katılıma açık, şeffaf, hesap verebilir ve etkinliğe odaklanmasını ortaya koyduğu için; kamu yönetiminde paradigma değişimini de gerekli kılmaktadır. Bu kapsamda klasik kamu yönetiminden yeni kamu yönetimi anlayışına geçiş, yönetişimin güçlendirilmesi için önemli bir basamağı oluşturmaktadır. Geleneksel kamu yönetimi anlayışı katı bir bürokrasi içerisinde dışa kapalı şekilde çalışmaların gerçekleştirmesini benimsemektedir. Bunun yanında merkeziyetçi bir anlayışla çalışmaları gerçekleştirmek ve hizmet anlayışı yerine kuralları uygulamak geleneksel kamu yönetiminde temel bir prensip olarak görülmektedir. Fakat özellikle 1980'lerden sonra kamu yönetimi anlayışında yaşanan paradigma değişimiyle yeni kamu yönetimi anlayışı gelişim göstermiştir. Bu kapsamda katı bürokratik örgütlenme yerine esnek örgütlenmeye gidilmesi, devletin faaliyet alanlarının küçültülmesi, performans hedeflerine göre çalışmaların gerçekleştirilmesi ve hesap verebilirliğin ön plana çıkması bu yeni kamu yönetim anlayışının temel prensipleri olmuştur (Yıldırım, 2018, s. 276-277). Geleneksel kamu yönetimi anlayışı ile yeni kamu yönetimi anlayışının detaylı karşılaştırmasını Tablo 1 üzerinden incelemek mümkündür;

Tablo 1. Geleneksel ve yeni kamu yönetimi anlayışının karşılaştırması

\begin{tabular}{|c|c|c|}
\hline & Geleneksel Yönetim & Yeni Yönetim \\
\hline \multirow{7}{*}{ Yapı } & Katı örgüt yapısı & Esnek örgüt yapıs1 \\
\hline & Merkeziyetçi & Adem-i merkeziyetçi \\
\hline & Katı hiyerarşi & Yumuşak hiyerarşi \\
\hline & Geniş merkez & Dar merkez - Geniş çevre \\
\hline & Hizmet devleti & Minimal devlet \\
\hline & Büyük ölçekli yap1 & Küçük ölçekli yap1 \\
\hline & Bürokrasi yönelimli & Piyasa yönelimli \\
\hline \multirow{16}{*}{ Roller İlkeler Politikalar } & Yönetim & İşletme \\
\hline & Örgüt merkezli & Vatandaş merkezli \\
\hline & Kurallara bağ ${ }_{1}$ & Performans hedefli \\
\hline & Sevk ve idare & Yönetişim \\
\hline & Sabit ücret & Performansa bağlı ücret \\
\hline & Bürokrat tipi yönetici & Girişimci yönetici \\
\hline & Az yetkili yönetici & Yetkilendirilmiş yönetici \\
\hline & Gizlilik & Şeffaflık \\
\hline & Hizmetlerde nicelik & Hizmetlerde kalite \\
\hline & $\begin{array}{l}\text { Üst yöneticiye bağl1 } \\
\text { Değerlendirme }\end{array}$ & Çok yönlü değerlendirme \\
\hline & Kapalı enformasyon kanalları & Açık enformasyon kanalları \\
\hline & Yetkiyi toplayan & Yetkiyi paylaşan \\
\hline & Risk almayan & Risk almakta istekli \\
\hline & Kuralcı ve kırtasiyeci & Vizyon sahibi \\
\hline & Girdi ve süreç odaklı & Çıktı ve sonuç odaklı \\
\hline & Birey yönelimli & Ekip yönelimli \\
\hline
\end{tabular}

Kaynak: Ery1lmaz, 2013, s. 58.

Kamu yönetiminde yaşanan bu paradigma değişimiyle birlikte, yeni kamu yönetimi anlayışı geliştikçe; devlet örgütlenmesinin yatay bürokrasiye yöneldiği, hesap verebilir hale geldiği, performans esaslı çalıştığ 1 , etkinlik ve verimliliği esas aldığı, vatandaş merkezli hale geldiği ve halkın görüşlerine daha çok değer verdiği görülmektedir. Yönetişim kavramı, yönetme sorumluluğunun devletten sivil topluma kaymasına işaret ettiği için, yeni kamu 
yönetimi anlayışının önemli bir parçası olarak bu süreçte gelişim göstermiştir. Bu kapsamda yönetişim kavramının yeni kamu yönetimi anlayışını beslediği, yeni kamu yönetimi anlayışının da yönetişimi beslediği söylenebilir. Bu durumda karşıllklı bir etkileşimden söz edilebilir. Bu etkileşim ve değişimin temelinde sivil toplum yer almaktadır. Yönetişim ve yeni kamu yönetimi anlayışı sivil toplumun daha iyi hizmet alması için geliştirilmişlerdir. Burada sivil toplumun kamu idaresine iki şekilde katılımı bulunmaktadır. İlki siyasal katılımdır ve sivil toplumun kendini yönetecek siyasal yöneticilerini yerel-ulusal düzeyde seçmesini ifade etmektedir. Bir diğeri yönetsel katılım olup, seçim faaliyetleri dışında kamu hizmetlerine yönelik kararların alınmasina katılımdır (Eryılmaz, 2013, s. 60-62). Bu kapsamda kamu idaresinde karar alma ve faaliyetleri geliştirme süreçlerine sivil toplumun katılmasını öngören yönetişimin, kamu idare anlayışının geleceğinde önemli bir etken olmaya devam edeceği öngörülebilir.

\subsection{Kamuda Yönetişimin Uygulanma Alanı ve Yerel Yönetişim}

Yönetişim kavramı insan unsuru ile ilgili olduğu için, insanın olduğu tüm yönetim sistemlerinde yönetişim uygulamalarına rastlanabilmektedir. Bu kapsamda kamu idare sisteminde yönetişimin uygulanma ölçeğini küresel, ulusal ve yerel seviyede ele almak mümkündür.

- Küresel Yönetişim: Küresel seviyede ortak kabul edilmiş hedeflere ulaşılması için ulusal hükümetlerin, kamu kurumlarının ve sivil toplumların bir araya getirilmesini ifade etmektedir. Böylece küresel zorlukların üstesinden gelinmesi için stratejik yaklaşımla ortak enerjilerin birleştirilmesi mümkün hale gelebilmektedir (Boughton ve Bradford, 2007, s. 11). Uluslararası Para Fonu (IMF), Dünya Bankası (WB), Dünya Sağl1k Örgütü (WHO) ve Birleşmiş Milletler (UN) gibi küresel organizasyonlar küresel yönetişimi tesis eden aktörler olarak tanımlanabilirler.

- Ulusal Yönetişim: Ulusal ölçekte tek yönlü kamu idare sisteminden ziyade; sivil toplum kuruluşlarını, özel sektörü ve doğrudan halkı yönetim süreçlerine dâhil etmeyi benimseyen yönetişim şeklidir (Özgökçeler, 2014, s. 72). Kamuda stratejik planlamaların yapılmasına halkın katılımı, e-devlet uygulamaları, vatandaş memnuniyet araştırmaları, performans programları, faaliyet raporları, denetim raporlarının halka açılanması, bilgi edinme hakk1 ve referandum gibi uygulamalar bu kapsamda değerlendirilebilirler.

- Yerel Yönetişim: Kamu idare sisteminde yönetişimin küresel ve ulusal seviyeden sonra en alt kademedeki uygulama alanı yerel yönetimler ölçeğinde gerçekleşmektedir. Yerel yönetimler doğrudan demokrasi okulu işlevi gördüklerinden, aynı zamanda kamu idareleri arasında yerel halkın doğrudan yönetici ve politika belirleyici olduğu kurumlardır. Dolayısıyla yerel yönetişimle kastedilen; yerel nitelikli kararların alınmasında özel sektör, sivil toplum ve STK'ların birer paydaş olarak öne çıkmalarıdır. Böylece hizmetlerin sunumunda etkinliğin ve verimliliğin sağlanabileceği düşünülmektedir. Bu düzenleme içerisinde halkın temsil, denetleme ve karar almada daha çok imkâna sahip olması da hedeflenmektedir (Güven ve Alan, 2018: 842). Ebelediyecilik uygulamaları, plebisitler, bilgi edinme hakk1, kent konseyleri, belediye meclisleri, halk günleri ve kamuoyu araştırmaları gibi uygulamalar yerel yönetişimin unsurları olarak kullanılabilmektedirler.

Yerel yönetişimin geliştirilmesi için de prensipler belirlenebilmektedir. Bu kapsamda Avrupa Konseyi doğrudan yerel yönetişimi geliştirmek için 2008 yılında 12 prensip belirlemiştir. $\mathrm{Bu} 12$ prensibi uygulayan yerel idarelere Avrupa Konseyi tarafindan ödül de verilmektedir. Türkçeye, "Yönetişimde Mükemmellik Avrupa Etiketi" (European Label of Governance' Excellence) olarak çevrilebilecek bu ödülü almak için yerel yönetimlerin belirlenmiş 12 prensibi sağlamaları gerekmektedir. Bu prensiplere göre iyi yerel yönetişim prensipleri şu şekildedir (Avrupa Konseyi, 2018a); 
- Adil Seçimler, Temsil ve Katılım: Yerel seçimler uluslararası standartlara ve ulusal mevzuata göre ve herhangi bir sahtekârlık olmadan özgürce ve adil bir şekilde yapılmalıdır. Vatandaşlar kamu faaliyetinin merkezinde yer almalıdırlar. Tüm erkekler ve kadınlar karar alma sürecinde kendilerini doğrudan veya dolaylı temsil eden meşru ara organlar aracılığıyla ses sahibi olabilmelidirler. Geniş katılım, ifade, toplanma ve örgütlenme özgürlüğü temel hak olarak görülmelidir. Kararlar çoğunluğun isteğine göre alınırken, azınlığın haklarına ve meşru çıkarlarına saygı duyulmalıdır.

- Duyarlılık: Amaçlar, kurallar, yapılar ve prosedürler vatandaşların meşru beklentilerine ve ihtiyaçlarına uyarlanmalıdır. Kamu hizmetlerinin sunumunda talepler ve şikâyetler makul bir süre içerisinde yanıtlanmalıdır.

- Etkinlik ve Verimlilik: Sonuçlar, kararlaştırılan hedeflere uygun olmalıdır. Performans yönetim sistemleri, hizmetlerin verimliliğini ve etkinliğini değerlendirmeyi ve iyileştirmeyi mümkün kılmalıdır. Denetimler, performansın değerlendirilmesi ve iyileştirilmesi için düzenli aralıklarla yapılmalıdır.

- Açıklık ve Şeffafık: Kararlar, kurallara ve düzenlemelere uygun olarak alınmalı ve uygulanmalıdır. Yasalarca iyi tanımlanmış nedenlerle sınırlandırılmamış tüm bilgilere kamu erişimi olmalıdır. Kararlar, politikaların ve sonuçların bilgilerini de içerecek şekilde kamuya duyurulmalıdır.

- Hukukun Üstünlüğ̈̈: Yerel makamlar yasalara ve adli kararlara uymalıdır. Kurallar ve düzenlemeler, yasalarca öngörülen prosedürlere uygun olarak kabul edilmeli ve tarafsız bir şekilde uygulanmalıdır.

- Etik Davranış: Kamu yararı bireysel çıkarların önünde olmalıdır. Her türlü yolsuzluğun önlenmesi için etkili tedbirler alınmalıdır. Çıkar çatışmaları zamanında ilan edilmelidir.

- Yetki ve Kapasite: Yönetişimi sağlayanların mesleki becerileri sürekli olarak geliştirilmelidir. Kamu görevlileri performanslarını sürekli iyileştirmek için motive edilmelidirler. Görevlilerin kapasitelerini geliştirmek için pratik yöntemler ve prosedürler oluşturulmalıdır.

- Yenilik ve Değişime Açıklık: Sorunlara yeni ve etkili çözümler aranmalı ve modern hizmet sunum yöntemlerinden yararlanılmalıdır. Yeni programları denemeye ve başkalarının deneyimlerinden öğrenmeye açık olunmalıdır. Daha iyi sonuçlar elde etmek için değişime elverişli bir iklim yaratılmalıdır.

- Sürdürü̈lebilirlik ve Uzun Süreli Oryantasyon: Mevcut politikalarda gelecek nesillerin ihtiyaçları dikkate alınmalıdır. Topluluğun sürdürülebilirliği sürekli olarak dikkate alınmalıdır. Gelecek nesillere çevresel, yapısal, finansal, ekonomik veya sosyal sorunlar aktarılmamalıdır. Yerel topluluğun geleceği hakkında geniş ve uzun vadeli bir bakış açısı kullanılmalıdır.

- Güçlü Finansal Yönetim: Ücretler, sunulan hizmetlerin maliyetini aşmamalı ve özellikle önemli kamu hizmetlerinde talebi aşırı derecede düşürmemelidir. Faaliyetler sırasında kredi kullanımında, kaynakların kullanımında, gelirlerin kullanımında ve rezervlerin kullanımında ihtiyat gözetilmelidir. Halka danışılarak çok yıllı bütçe planları hazırlanmalıdır. Riskler, kamu-özel ortaklıklar arasında paylaşılmalıdır.

- İnsan Hakları, Kültürel Çeşitlilik ve Sosyal Uyum: Yerel otoritenin nüfuz alanı içerisinde insan haklarına saygı duyulmalı, korunmalı ve her hangi bir nedenle ayrımcılık yapılmamalıdır. Kültürel çeşitlilik bir kazanım olarak kabul edilmeli ve herkesin yerel toplulukta bir payının olması için çaba sarf edilmelidir. Sosyal uyum ve dezavantajlıların entegrasyonu teşvik edilmelidir.

- Hesap Verebilirlik: Tüm karar vericiler, toplu ve bireysel kararları için sorumluluk almalıdır. Yanlış kararlarla ilgili cezalandırma yapılmalıdır. Kötü yönetime karşı etkili çözümler geliştirilmelidir. 


\subsection{Yerel Yönetişimin Mevzuatlarla Geliştirilmesi: Türkiye Örneği}

Yerel yönetişim uygulamalarını geliştirmek için mevzuatlar ortaya konulabilmektedir. $\mathrm{Bu}$ mevzuat uygulama örneklerini Türkiye ölçeğinde somut bir şekilde tespit etmek mümkündür. Türkiye'de yerel yönetimler belediye, il özel idaresi ve köy yönetimlerinden teşekkül ederken, bunlar arasında sahip olunan yetki ve bütçe ile en öne çıkanı belediyelerdir. Belediyeler, Türkiye'de kentlerin ekonomik, sosyal ve fiziksel yönden en önemli hizmet yüklenicisidirler. Bu sorumluluklarından dolayı kentlerin sorunlarını çözmek ve geleceklerini kurgulamak doğrudan belediyelere bırakılmıştır. Dolayısıyla yerel yönetişimin en geniş ölçekte belediyelerde hayata geçirilmesi ve halkın belediyelerin çalışmalarına katılım sağlaması, yönetişimin geliştirilmesi için bir gereklilik olarak görülebilir. Bu kapsamda 5393 sayılı Belediye Kanunu, Kent Konseyi Yönetmeliği ve 4982 sayılı Bilgi Edinme Hakkı Kanunu yönetişimi belediyelerde mümkün k1lan düzenlemelere sahiptir.

5393 sayıl Belediye Kanunu: Belediyelerin tüzel kişiliğini düzenleyen bu kanun aynı zamanda yönetişimi geliştirici düzenlemelere de sahiptir. Örneğin muhtarlar mahalle sakinlerinin gönüllü katılımıyla ortak ihtiyaçları belirleyerek, mahallesinin yaşam kalitesini geliştirmek için diğer kamu kurumlarıyla iş birliği yapmakla görevlendirilmiştir (Md. 9). Tüm vatandaşlar ikamet ettikleri yerleşim yerinin hemşehrisidir. Bu insanlar belediye karar alma süreçlerine katılma ve belediye faaliyetleriyle ilgili bilgi edinme hakkına sahiptirler. Bunun yanında belediyeler de hemşehriler arasında sosyal ilişkilerin geliştirilmesi için çalışma yapmakla görevlendirilmişlerdir (Md. 13). Belediyeler, halkın belediye hizmetleriyle ilgili görüşlerini tespit etmek için kamuoyu yoklaması yapabilirler (Md. 15). Meclis toplantı gün ve saatleri halka duyurulmalıdır ve meclis toplantıları halka açık gerçekleştirilmelidir (Md. 20). Meclis gündemi önceden halka duyurulmalıdır (Md. 21). Kesinleşen meclis kararlarının özetleri yedi gün içerisinde halka duyurulmalıdır (Md. 23). Muhtarlar, ildeki kamu kuruluşu amirleri, kamu kuruluşu niteliğindeki meslek kuruluşları, sendikalar, üniversiteler ve sivil toplum örgütlerinin temsilcileri kendi konularıyla ilgili meclis ihtisas komisyonlarına katılabilirler (Md. 24). Belediyeler tarafından hazırlanan stratejik planlar üniversitelerin, meslek odalarının ve sivil toplum kuruluşlarının görüşlerini alarak hazırlanır (Md. 41). Belediyelerde kent konseyi oluşturulmaktadır ve bu konseylerde kamu kurumu niteliğindeki meslek kuruluşlarının, noterlerin, üniversitelerin, sendikaların, sivil toplum örgütlerinin, siyasi partilerin, muhtarların ve diğer ilgili temsilcilerin yer alması sağlanır. Kent konseyinde alınan kararlar belediye meclisinin ilk toplantısında görüşülür ve karara bağlanır (Md. 76). Belediye; eğitim, spor, sağlık, çevre ve diğer hizmetlerin gerçekleştirilmesinde; ayrıca engellilere, kadınlara, çocuklara, yaşlılara ve düşü̈nlere yönelik hizmetlerde halkın gönüllü katılımını sağlamaya yönelik tedbirler almalıdır (Md. 77) (5393 sayılı Belediye, 2005).

Kent Konseyi Yönetmeliği: 2006 yllında kabul edilen Kent Konseyi Yönetmeliği, kent yaşamında hemşehrilik bilincinin geliştirilmesinin yanında; dayanışma, hesap sorma, katılım, yerinden yönetim ve yönetişim ilkelerinin hayata geçirilmesini hedefleyen kent konseylerinin çalışma esaslarını düzenlemektedir. Kent konseyinin görevleri özetle şu şekildedir; yerel düzeyde katılımı ve çok aktörlü yönetişimi geliştirmek; kente yönelik stratejilerde tüm kenti kapsayan ortak aklı geliştirmek; yerellik ilkesi temelinde katılımc1lığ ve demokrasiyi geliştirmek; sivil toplumun gelişmesine katkıda bulunmak; gençlerin, çocukların, kadınların ve engellilerin yerel karar mekanizmalarına katılımlarını sağlamak; kent yönetiminde katılım, hesap verme ve saydamlık ilkelerini geliştirmek (Md. 6). Kent konseyleri; mülkün idare amiri veya temsilcisi, belediye başkanı veya temsilcisi, kamu kuruluşlarının temsilcileri, belediye meclis üyeleri, il genel meclis üyeleri, muhtarlar, siyasi parti temsilcileri, üniversite temsilcileri, meslek kuruluşları temsilcileri, sendika temsilcileri, baro temsilcileri ve kooperatiflerin temsilcileri üzerinden oluşturulmaktadır (Md. 8) (Kent Konseyi Yönetmeliği, 2006).

4982 sayılı Bilgi Edinme Kanunu: Türkiye'de vatandaşların tüm kamu kurumlarının faaliyetleriyle ilgili bilgi edinme hakkı bulunmaktadır. Bilgi Edinme Kanunu bu durumu düzenlemektedir. Kanunun amacı özetle şu şekildedir; şeffaf ve demokratik yönetimin gereği 
olarak açıklık ilkesine göre kişilerin bilgi edinme hakkını düzenlemek (Md. 1). Kanun uyarınca herkes bilgi edinme hakkına sahiptir (Md. 4). Kurumlar gizli olması gerekmeyen tüm bilgileri kendilerine başvuranlara paylaşmakla yükümlüdürler (Md. 5) (4982 sayılı Bilgi Edinme, 2003).

Bu temel kanun ve yönetmeliklerin yanında Türkiye ölçeğinde belediyelerin beyaz masa uygulamaları, e-belediyecilik uygulamaları, halk günleri, mahalle toplantıları ve dilekçe uygulamaları da yerel yönetişimi geliştiren uygulamalar olarak değerlendirilebilirler.

\section{Avrupa Konseyi ve 12 Yıldızlı Şehir Uygulaması}

Yerel yönetişimin geliştirilmesi alanında Avrupa Konseyi’nin çalışmaları bulunmaktadır. Avrupa Konseyi'nin bir üyesi olan Türkiye de yerel yönetişimi geliştirmeyi hedefleyen bu çalışmaların bir muhatabıdır. Konuyla ilgili olarak çalışmanın bu kısmında Avrupa Konseyi ve 12 Yıldızlı Şehir uygulaması açıklanmıştır.

\subsection{Avrupa Konseyi}

Avrupa Konseyi 1949 yılında kurulmuş bir uluslararası örgüttür. Temel hedefleri hukukun üstünlüğünü tesis etmek, insan haklarını güvence altına almak ve çoğulcu demokrasi ilkelerini geliştirmektir. Örgüt, II. Dünya Savaşı sonrası büyük maddi, manevi ve beşeri kaynak kaybeden Avrupa'nın yeniden bütünleşmesi amaciyla kurulmuştur. Avrupa devletleri arasında ortak sözleşmeler, çalışmalar ve kanunlar yaparak, bütünleşmeyi güçlendirmeyi amaçlamıştır (Avrupa Konseyi, 2018b). Avrupa ülkeleri üzerine çalışan örgütün şu anda 47 üyesi bulunmaktadır. Türkiye 13. üye olarak 1950 yılında örgüte katılmıştır ve günümüzde hala örgütün bir üyesi konumundadır (Avrupa Konseyi, 2018c).

\subsection{Avrupa Konseyi Yerel ve Bölgesel Yönetimler Kongresi}

Avrupa Konseyi Yerel ve Bölgesel Yönetimler Kongresi (Council of Europe's Congress of Local and Regional Authorities), Avrupa Konseyi üyesi olan 47 ülkede yerel ve bölgesel demokrasiyi geliştirmek üzere çalışmalarını yürütmektedir (Avrupa Konseyi, 2018ç). İlk temeli 1957 y1lında "Konferans" olarak atılmış olmakla birlikte, resmi olarak 1994 tarihinde "Kongre" statüsüne dönüştürülmüştür (Avrupa Konseyi, 2018d). Kongrenin ikili bir meclis yapıs1 bulunmaktadır. Birisi "Yerel Yönetimler Odası" (Chamber of Local Authorities) diğeri ise "Bölgeler Odası" (Chamber of Regions) şeklindedir (Avrupa Konseyi, 2018e). Kongrenin en önemli görevlerinden birisi 1985 tarihinde imzaya açılan Avrupa Yerel Yönetimler Özerklik Şartı'nın, Avrupa Konseyi üyesi 47 ülkedeki uygulamalarını izlemektir. Avrupa Yerel Yönetimler Özerklik Şartı bilindiği üzere Avrupa ülkelerinde yerel özerkliği tesis etmek ve geliştirmek üzere oluşturulmuş bir metindir. Avrupa Konseyi'ne üye ülkeler bu metnin maddelerine imza vererek kendi ülkelerinde şartın maddelerini yerine getirmeye çalışmaktadırlar (Avrupa Konseyi, 2018f). Bunun yanında Kongrenin, Avrupa Konseyi'ne üye ülkelerde yerel seçimleri takip etme, yerel yönetimlerin özerklik ve demokratik çalışma prensiplerini izleme gibi görevleri de bulunmaktadır (Avrupa Konseyi, 2018g). Kongre ilgili izleme faaliyetlerini raporlar haline getirerek ilan etmektedir. Kongrenin bir diğer çalışması da Avrupa Konseyine üye 47 ülkede Avrupa Yerel Demokrasi Haftası organize etmektir.

\subsection{Avrupa Yerel Demokrasi Haftası}

Avrupa Konseyinin 47 üye ülkesine yönelik olarak yıllık Avrupa Yerel Demokrasi Haftası (European Local Democracy Week - ELDW) etkinliği gerçekleştirilmektedir. Etkinliğin temel amacı yerel düzeyde yerel yönetişimi/katılımı geliştirmektir. Avrupa Yerel Demokrasi Haftası her y1l 15 Ekim tarihine denk gelen haftada organize edilmektedir. Bunun nedeni 15 Ekim 1985 tarihinde imzaya açılan Avrupa Yerel Yönetimler Özerklik Şartı'nı hatırlatmaktır (Avrupa Konseyi, 2018 ğ). Dolayısıyla yerel yönetişimin geliştirilmesi de bu kapsamda temel bir çalışma alanı meydana getirmektedir. Avrupa Yerel Demokrasi Haftası'nın temel amacı; insanların yerel yönetimlerin çalışmalarına katılımlarını arttırmaktır. Bunun yanında hedefler ise şu şekildedir (Avrupa Konseyi, 2018h); 
- Temel seviyede yerel demokratik katılımı Avrupa'da tesis etmek ve geliştirmek;

- Vatandaşların yerel yönetimlerin nasıl çalıştığı konusundaki farkındalığını artırmak;

- Avrupa genelinde yerel seçilmiş temsilcilerin ne yaptıklarını tespit etmek;

- Yerel karar alma süreçlerinde yer alma firsatları hakkında insanları bilgilendirmek;

- Vatandaş katılımını artırmak için düzenlenen etkinliklerden üyeleri haberdar etmek;

- Üyelerin birbirlerinin deneyimlerinden fikir ve ilham almalarını sağlamak.

Avrupa Yerel Demokrasi Haftası'nda yer alan aktörler başta yerel yönetimler (yerel yönetimlere belediyeler, bölge yönetimleri, meclisler, yerel yönetim birlikleri de dâhildir) olmak üzere sivil toplum ve sivil toplum kuruluşlanıdır. Organizasyon kapsamında yer alan aktörler bu etkinliğe ilişkin kayıt yaptırmaktadırlar ve bu organizasyonu icra edeceklerini kendi bölgelerinde halka duyurmaktadırlar. 2007 yılından beri gerçekleştirilen Avrupa Yerel Demokrasi Haftası'nın her yıl belirlenmiş tematik etkinlikleri olmaktadır. İlgili haftaya dâhil olacak aktörlerin bu etkinlikleri kayıt yaptırdıkları yılın 15 Ekim tarihine denk gelen haftada gerçekleştirmeleri kendilerinden beklenmektedir. Örneğin 2018 y1lı için belirlenmiş olan tematik etkinliklerin temelinde "çocuk ve gençlere yönelik yerel yönetişim etkinliklerinin yapılması" ana hedef olarak belirlenmiştir. Bunun yanında 2018 Ekim ayı için belirlenmiş olan üç yan tematik etkinlik ise şu şekildedir (Avrupa Konseyi, 2018h);

1. Yerel düzeyde istişarenin ve aktif vatandaşlığın teşvik edilmesi amacıyla diyalog imkânı ve ortamı oluşturmak.

2. İnsan hakları ve demokratik yurttaşlık konusunda eğitimler vermek.

3. Genç vatandaşların yerel kamu politikalarının geliştirilmesine katılımını teşvik etmek.

\subsection{Avrupa Yerel Demokrasi Haftası Etkinliklerine Katılan Aktörler}

Avrupa Yerel Demokrasi Haftas1 etkinliklerine 2018 yılında katılmış olan yerel aktörleri tespit etmek mümkündür. Tablo 2'de yer alan yerel aktörler arasında belediyeler, bölge yönetimleri, köy idareleri, dernekler, sivil toplum kuruluşları ve diğer organizasyonlar bulunmaktadır.

Tablo 2. 2018 Avrupa Yerel Demokrasi Haftası'na katılan yerel aktörler

\begin{tabular}{cl}
\hline Ülke & \multicolumn{1}{c}{ Yerel Aktör } \\
\hline Arnavutluk & Kamez Belediyesi \\
\hline Ermenistan & Vanadzor \\
\hline Belçika & Bürüksel Başkent Bölgesi Belediyeleri \\
\hline Fransa & Bischwiller, Strasbourg, Commune de Grendelbruch \\
\hline Gürcistan & Gürcistan Ulusal Yerel Yönetimler Birliği \\
\hline Almanya & Chemnitz, Civocracy \\
\hline Yunanistan & Farkadona, Katerini Gençlik Ağı \\
\hline Macaristan & Cselekvö Lepseny, Macar Ulusal Yerel Yönetimler Birliği \\
\hline İtalya & Associazione Volontarimini, Regione Emilia-Romagna, Association Darśana Teranga \\
\hline Malta & Aktif Uluslararası Gençlik Organizasyonu \\
\hline Hollanda & Vlaardingen \\
\hline Polonya & Lodz \\
\hline Portekiz & Amadora, Municipio de Gondomar, Municipio do Funchal, Municipio of Valongo, Municipio de \\
\hline Romanya & Medgidia, Mioveni, Ramnicu Valcea, Entegrasyon Yasası Derneği \\
\hline İspanya & El Turro \\
\hline İsveç & Huddinge, Södermöre-Kalmar \\
\hline Ukrayna & Fastiv, Kharkiv, Kiev, Lviv Kent Konseyi \\
\hline Birleşik & Amanda Shaw, Aylesbury, Chesterfield Borough Council, Kirklees, Malvern Hills, Merton TV. \\
\hline Krallı & \\
\hline
\end{tabular}




\begin{tabular}{ll}
\hline \multirow{5}{*}{ Türkiye } & Ahmetbey Belediyesi, Büyükçekmece Belediyesi, Bağcılar Belediyesi, Beşiktaş Belediyesi, Edremit \\
& Belediyesi, İzmit Belediyesi, Kadıöy Belediyesi, Kahramankazan Belediyesi, Karşıyaka Belediyesi, \\
& Keçiören Belediyesi, Lüleburgaz Belediyesi, Kırklareli Belediyesi, Rize Belediyesi, Zeytinburnu \\
& $\begin{array}{l}\text { Belediyesi, Maltepe Belediyesi, Sarıyer Belediyesi, Sarıyer Kent Konseyi, Marmara Belediyeler } \\
\text { Birliği }\end{array}$ \\
\hline
\end{tabular}

\section{Kaynak: Avrupa Konseyi, 2018i}

Tablo 2'ye göre Türkiye'den yerel yönetimlerin, Avrupa Yerel Demokrasi Haftası etkinliklerine katılma konusunda diğer Avrupa yerel yönetimlerinden daha istekli oldukları görülmektedir. Bu kapsamda ilgili etkinliğe 2018 yılında Türkiye'den 18 yerel yönetim aktörü katılım gösterirken, Portekiz'den 7, Birleşik Krallık'tan ise 6 yerel yönetim aktörünün katılım sağladığı görülmektedir. Türkiye'den etkinliğe katılım sağlayan yerel yönetim (belediye) sayısının 16 olduğu göz önüne alındığında, Avrupa Yerel Demokrasi Haftası'na 2018 yılında en çok katılım sağlayan yerel yönetimlerin Türkiye'den olduğu dikkat çekmektedir.

\section{5. "12 Yıldızlı Şehir” (12 Star City) Uygulaması}

Avrupa Yerel Demokrasi Haftası'nda o yılın tematik etkinliklerini yerine getiren ve yerel yönetişim alanında ilgili çalışmaları yapan yerel yönetimlere "12 Yıldızlı" (12 Stars) payesi verilmektedir. 12 yıldız, Avrupa Birliği flamasında yer alan ve Avrupa Birliği'ni temsil eden yıldızlara atıf yapmaktadır. Böylece ilgili yerel yönetimin, yerel yönetişim alanında çalışmalar yapan bir yerel aktör olduğunu tescillemesi mümkün olmaktadır. Fakat bu statü yıllık olarak verilmektedir. Her yıl Avrupa Yerel Demokrasi Haftası etkinlikleri gerçekleştiren ve ilgili kriterleri yerine getiren yerel yönetimler bu unvanı tekrar alabilmektedirler. Bu 12 Yıldızlı Şehir statüsünün alınması için beş kriter belirlenmiştir ve ilgili yerel yönetimin bu beş kriteri Avrupa Yerel Demokrasi Haftası kapsamında aynı anda sağlaması gerekmektedir. Bu kriterler şu şekildedir (Avrupa Konseyi, 20181);

1. Avrupa Yerel Demokrasi Haftası faaliyetleri için özel bir bütçe tahsis etmek. (Bu bütçe başka kurumlar tarafından da finanse edilebilir. Örneğin yerel kamu hizmeti sağlayıcıları, diğer yerel yönetimler, sponsorlar, vd.).

2. Avrupa Konseyi Yerel ve Bölgesel Yönetimler Kongresi tarafindan kararlaştırılan Avrupa Yerel Demokrasi Haftası görsel kimliğini kullanarak bir tanıtım kampanyası gerçekleştirmek (posterler, afişler, anonslar, vd.).

3. Yılın önde gelen teması ile bağlantılı bazı özel aktiviteler gerçekleştirmek.

4. Avrupa Yerel Demokrasi Haftası'nı oluşturan etkinliklere farklı vatandaş gruplarını dâhil etmek. Özellikle belediye gençlik konseyleri ile okul öğrencilerinin katılımına önem vermek.

5. Yerel otoritelerin demokratik bir Avrupa'nın inşasında rolünü göstermek için, Avrupa çapında bir etkinlik düzenlemek. Bu kapsamda Avrupa Konseyi Yerel ve Bölgesel Yönetimler Kongresi'nden bir yetkili davet edilebilir ve kendisinin konuşma yapması sağlanabilir.

Bu 12 Yıldızlı Şehir statüsünü almak için, Avrupa Yerel Demokrasi Haftası'ndan ayrı olarak yerel yönetimler tarafından ayrı bir başvuru yapılmalıdır. Bu kapsamda yerel yönetimler internet üzerinden Avrupa Konseyi Yerel ve Bölgesel Yönetimler Kongresi'nin belirlediği internet sitesine gerekli şekil ve şartlarda başvuru yapmaktadırlar. Böylece yerel yönetişimi sağlamak adına çalıştıklarını Avrupa Birliği düzeyinde tescil edebilmektedirler. Burada faaliyetleri kabul edilen yerel yönetimler Avrupa Konseyi'nin merkezi Strasbourg'da düzenlenen bir törenle "12 Yıldızlı" statülerini almaktadırlar. İlgili yerel yönetimin bulunduğu şehir de "12 Yıldızlı Şehir" statüsü almaktadır.

\section{Türkiye’de 12 Yıldızlı Şehir Statüsü Alan Yerel Yönetimler ve Uygulamaları}

Avrupa Yerel Demokrasi Haftası kapsamında Türkiye'den yerel yönetimler çalışma gerçekleştirmektedirler. İçişleri Bakanlığı verilerine göre Türkiye'de 1399 belediye, 51 il özel idaresi ve 18.335 köy idaresi bulunmaktadır (İçişleri, 2018). Fakat Tablo 2'de görüldüğü üzere 
bu etkinliğe Türkiye'de sadece belediyeler ilgi göstermektedir. İl özel idarelerinin, köy idarelerinin, STK'ların veya diğer yönetişim aktörlerinin bu etkinliğe katılım sağlamadıkları görülmektedir. $\mathrm{Bu}$ etkinlikten Türkiye'deki belediyeleri haberdar etmek için Türkiye Belediyeler Birliği duyurular yapmaktadır. Ayrıca ilgili belediyelere yönelik örnek çalışmalar da bu duyurular sırasında tanıtılmaktadır (Türkiye Belediyeler Birliği, 2018). Bu kapsamda Türkiye belediyelerinden 12 Yıldızlı Şehir statüsünü daha önce alanlar ve bu statüyü almaya ilk defa aday olanlar mevcuttur. 2019 yılında, daha öncesinden alınmış olan 12 Yıldızlı Şehir statüsünü tekrar almak isteyen veya bu statüyü ilk defa 2019 yılında almak isteyen belediyelerin 2018 yılında yaptıkları çalışmaları aşağıda sıralamak mümkündür. 2018 yılı için belirlenmiş olan tematik etkinliklerde "çocuk ve gençlere yönelik yerel yönetişim etkinliklerinin yapılması" temel hedef olarak belirlenmiştir. Dolayısıyla 12 Yıldızlı Şehir statüsü almak için ilgili belediyelerin 2018 Ekim ayının 15'nci gününe denk gelen haftada çocuk ve gençlere yönelik yerel yönetişim etkinlikleri yapmaları gerekmiştir. 2019 yılında 12 Yıldızlı Şehir statüsünü pekiştirmek için veya ilk defa bu statüyü almak için, 2018 Ekim ayında çalışma yapan belediyelerin yaptıkları çalışmalar şu şekildedir (Avrupa Konseyi, 2018i);

Ahmetbey Belediyesi: Ahmetbey Belediyesi, Kırklareli'ne bağlı Lüleburgaz ilçesinin beldesi konumundadır. Bu konumuyla Türkiye'de 12 Yıldızlı Şehir unvanı alan ilk belde belediyesi olmuştur. 2017 yılında yaptığı çalışmalarla 2018 yılında 12 Yıldızlı Şehir unvanı alan belediye, 2019 yılında bu statüsünü korumak için 2018 yılında şu çalışmaları yapmıştır (Avrupa Konseyi, 2018j);

- Öğrencilerle "Ortak Akıl” Toplantısı ve Atölye Çalışması: İlköğretim, ortaokul ve lise ögrencileri ile Avrupa Yerel Demokrasi Haftası üzerine toplantı ve atölye çalışması gerçekleştirilmiştir.

- Gençlerin A Ăgz ve Diş Sağlı̆̆ı: Ahmetbey Atatürk İlköğretim Okulu ve Cumhuriyet İlköğretim Okulu öğrencilerine "Ăğız ve Diş Sağlığı" eğitimi gerçekleştirilmiştir. Ayrıca öğrencilere ücretsiz diş sağlığı kontrolü de yapılmıştır.

- Sınav Stresi İle Başa Çıkma Semineri: Lise öğrencileri bir psikolog ile sınav stresiyle başa çıkma üzerine seminer gerçekleştirmişlerdir.

- Halk Günü Ücretsiz Sağllk Taraması: Özel bir hastane tarafindan halk pazarında ücretsiz sağlık taraması yapılmıştır.

- Beldede Yaşayan Kadinlarla Toplantı: Belediye başkanı beldede yaşayan kadınlarla kahvaltıda bir araya gelerek belediye faaliyetleriyle ilgili görüşme yapmıştır.

- Imza Günü ve Fotoğraf Sergisi: Bir roman yazarı ile imza ve söyleşi günü tertip edilmiş; beldedeki siyasi partiler ziyaret edilmiştir.

- Kukla Gösterisi: Ahmetbey Atatürk İlkokulu ve Cumhuriyet İlkokulu öğrencileri için kukla gösterisi tertiplenmiştir.

Büyükçekmece Belediyesi: İstanbul'un ilçelerinden olan Büyükçekmece, 2012 yılından itibaren her yıl 12 Yıldızlı Şehir statüsü almaktadır. Belediye, 2019 yılında bu unvanı tekrar elinde tutmak için 2018 yılında şu çalışmaları yapmıştır (Avrupa Konseyi, 2018k);

- Geleneksel Belediye Meclisi Avrupa Yerel Demokrasi Haftası Resepsiyonu: Belediye meclisinin ekim ayı meclis toplantısında Avrupa Yerel Demokrasi Haftası ile ilgili resepsiyon düzenlenmiştir.

- Kahvehanelerde Dijitalleşme Ĕ̈itimi: Şehrin sınırları dâhilindeki kahvehanelerde, özellikle orta yaşlı ve yaşlı vatandaşlara akıllı telefonların kullanımı eğitimleri verilmiştir. Böylece insanların akıllı telefon uygulamalarını kullanabilmeleri ve mobil kamu hizmetlerinden yararlanabilmeleri öğretilmiştir.

- "Seçme ve Seçilme Hakkım!” Etkinliği: Belediyeye ait Öğrenci Çalışma Merkezi'ndeki ilköğretim öğrencilerine "Seçim, Seçme ve Seçilme" eğitimi verilmiştir. Eğitim, "nasıl aktif vatandaş olunacağı, belediyenin nasıl çalıştığı, demokrasinin 
temelleri” konularına dayanmıştır. Eğitimden sonra öğrenciler sınıf başkanlarını seçmişlerdir.

- Sivil Toplum ve Kamu Kurumları İşbirliği ile "Yönetişim”: Büyükçekmece Belediyesi, her yıl Belediye tarafindan yürütülen projeleri, faaliyetleri, yatırımları ve gelecek yıl için planlanan projeleri değerlendirmek üzere; STK'ların, özel kuruluşların ve vatandaşların seçtikleri mahalle temsilcileriyle toplantılar düzenlemektedir.

- Cumhuriyet Bayramı Kutlamaları ve Avrupa Onur Bayrağl: Cumhuriyet Bayramı kutlamalarının bir parçası olarak yapılan yürüyüşün ardından; Büyükçekmece vatandaşları, Avrupa Konseyi tarafından verilen "Onur Bayrağı" ödül törenini izlemek için Belediye Binası önünde toplanmışlardır. Bu ödül, Belediyenin, Avrupa Yerel Demokrasi Haftası kapsamında yürüttügü faaliyetlerini ödüllendirmek amacıyla verilmiştir.

- “Okulum ve Şehrim için Beni Dikkate Al!” Etkinliği: Belediyenin Öğrenci Merkezindeki öğrencilere seçimler hakkında dersler verilmiştir. Ayrıca öğrencilere yerel demokrasi, aktif vatandaşlık ve insan hakları konularında da eğitimler verilmiştir. Gençlere, belediye ile işbirliği yaparak şehirlerini yönetmeye nasıl katılabilecekleri de anlatılmıştır.

- Ö̆̆rencilerin Belediye Başkanlarıyla Buluşmaları: Büyükçekmece sınırları içinde bulunan Arel Üniversitesi'nden öğrenciler Belediye Başkanı ile bir araya gelmiştir. Öğrenciler yerel demokrasi, karar verme sürecinde vatandaşların katılımı ve belediyenin işleyişi hakkında sorular sormuşlardır.

- Halkın Evi- Büyükçekmece Belediyesi Etkinliği: Büyükçekmece Belediye Binası'nı 9-12 yaş arası ilkokul öğrencileri ziyaret etmişlerdir. Öğrenciler, Belediye Başkanı ile röportaj yaptıktan sonra, belediyenin her bir birimini ziyaret etmiş ve birimlerden hangi hizmetleri alabilecekleri konusunda bilgilendirilmişlerdir.

- Girişimciler Açısından "Vatandaş Katılımı": Büyükçekmece Belediyesi tarafından koordine edilen "Yeşil Girişimcilik ve Yenilikçi İstihdam Merkezi" projesi kapsamında Türkiye, Yunanistan, Macaristan ve Litvanya'dan 40 genç, "Yeşil Girişimcilik" eğitimine katılmıştır. Bu proje sırasında katılımcılar Avrupa Konseyi ve Avrupa Yerel Demokrasi Haftası hakkında bilgilendirilmiş ve "yerel demokrasiye vatandaşların katılımını artırmak için neler yapılabilir" konusunda genç katılımcılarla bir atölye çalışması yapılmıştır.

- Engelliler İçin Daha Kaliteli Hizmet: Belediye çalışanlarına engelli vatandaşlara daha kaliteli hizmet verebilmeleri için eğitimler verilmektedir. Örneğin 'Iş̧aret Dili Eğitimi' Halkla İlişkiler personeline işitme engelli vatandaşlarla iletişim kurabilmeleri için verilmiştir.

- Toplumsal Cinsiyet Eşitliği Eğitimi: Belediye personeli, çalışmalarında ve projelerinde cinsiyet eşitliğine duyarlı olmaları için eğitilmiştir.

Bağcılar Belediyesi: İstanbul'un bir diğer ilçesi olan Bağcıların 12 Yıldızlı Şehir statüsü bulunmaktadır. 2019 yılında bu unvanı tekrar elinde tutmak için 2018 yılında şu çalışmaları yapmıştır (Avrupa Konseyi, 20181);

- Seminer Etkinliği: Gençlerin yerel demokrasideki önemi ve Avrupa Yerel Demokrasi Haftası hakkında gençlere yönelik seminer etkinliği gerçekleştirilmiştir.

- Gençlik Festivali Etkinliği: Bağcılar Olimpiyat Spor Salonu'nda düzenlenen festivalde, eğitimden - spora çeşitli alanlarda başarılı olan gençler ödüllendirilmiştir.

Beşiktaş Belediyesi: İstanbul ilçesi Beşiktaş'ın 2017 yılından itibaren 12 Yıldızlı Şehir statüsü bulunmaktadır. 2019 yılında bu unvanı tekrar elinde tutmak için 2018 yılında şu çalışmaları yapmıştır (Avrupa Konseyi, 2018m); 
- Çocuk Dostu Şehirler Semineri: Seminer kapsamında belediye bünyesinde çalışan personele çocuk hakları ve çocukların kendi yaşamlarıyla ilgili karar alma hakları üzerine bilgilendirme yapılmıştır.

- Beşiktaş Şehri 'Avrupa Yerel Demokrasi Haftası' Yürüyüşü: Beşiktaş Belediyesi, Beşiktaşlı vatandaşların, sivil toplum kuruluşlarının, mahalle temsilcilerinin ve Belediye personelinin katılımıyla bir şehir turu düzenlemiştir. Amaç, Beşiktaş'1 simgeleyen değerlerin ve mekânların tarihi hakkında farkındalığı artırmak olmuştur.

Edremit Belediyesi: Balıkesir iline bağlı ilçe konumunda bulunan Edremit, 2018 yılında ilk defa aldığ 12 Yıldızlı Şehir statüsünü 2019'da da korumak için 2018 yılında şu etkinlikleri gerçekleştirmiştir (Avrupa Konseyi, 2018n);

- İda Dă̆ı'nın 4 Mevsimi - Fotoğraf Sergisi: Edremit bölgesinin sembolik özelliklerinden olan Kazdağları'nın tanıtımını gerçekleştirmek için bir fotoğraf sergisi düzenlenmiştir.

- Erasmus ve Gönüllülük Projeleri Bilgilendirme Toplantısı: Belediye tarafından Balıkesir Üniversitesi öğrencilerine yönelik olarak Erasmus ve gönüllülük üzerine seminer verilmiştir. Böylece Avrupa Birliği bünyesinde nasıl gönüllü çalışmalar yapılacağ 1 konusunda bilgilendirme gerçekleştirilmiştir.

- Castro ve Gaeta Belediye Başkanlarının Edremit Belediye Başkanlı̆̆ını Ziyareti: Edremit Belediyesi, Avrupa Yerel Demokrasi Haftas1 etkinliklerini kendi bünyesinde gerçekleştirirken, diğer belediyeleri de bu haftaya katılmaya teşvik etmeyi amaçlamıştır. Bu kapsamda iki İtalyan belediye başkan yardımcısını, bir kültür rotası belirlemek üzere davet etmiştir.

- Basın Toplantısı: Vatandaşları, 2018 Avrupa Yerel Demokrasi Haftas1 hakkında bilgilendirmek için, Belediye Başkanı bir basın toplantısı gerçekleştirmiştir.

- Demokrasi için Boyama Etkinliği: Ortaokul öğrencileriyle, Down sendromlu, zihinsel ve fiziksel engelli çocukları bir araya getirerek Edremit Belediyesi'nde sergilenmek üzere bir resim yapma etkinliği gerçekleştirilmiştir.

- 4 Tekerlekli Belediye Projesi: Vatandaşların başvuru, istek ve şikâyetlerini kayıt altına almak için, belediyenin mobil ofisi olarak kullanmak amacıyla bir minibüs restore edilmiştir ve kentin farklı noktalarında vatandaşların taleplerini iletmeleri için kullanılmaktadır.

- Çocuk ve Gençlik Politikalarını Tasarlama Etkinliği: Edremit Belediyesi, gelecek yıllardaki çocuk ve gençlik politikalarını doğrudan çocuklara sorarak tasarlamayı amaçlamıştır. Bu kapsamda belediye meclis salonunda bir araya getirilen çocuklara çeşitli seçenekler sunularak, kendilerine verilmesini istedikleri hizmetleri oylamaları istenmiştir.

- Belediye Başkanı ile Farklı Siyasi Partilerin Gençlik Temsilcileri Yuvarlak Masa Toplantısı: Etkinlik kapsamında Edremit ilçesinde bulunan farklı siyasi partilerin gençlik temsilcileri belediye başkanıyla bir araya gelerek, Avrupa Konseyi ilke ve değerleri hakkında konuşmuştur.

İzmit Belediyesi: Kocaeli'nin ilçesi konumunda bulunan İzmit Belediyesi, 12 Yıldızlı Şehir statüsünü ilk olarak 2016 yılında almıştır. Statüsünü 2019' da da korumak için 2018 yılında şu etkinlikleri gerçekleştirmiştir (Avrupa Konseyi, 2018o);

- Demokrasi Duvarı: Demokrasi Duvarı, İzmit Belediye'sine ait hizmet binalarının önünde kurulmuştur ve vatandaşların demokrasi hakkındaki düşüncelerini bu duvara yazmalarına olanak sağlanmıştır.

- Belediye Başkanına Mektup: Vatandaşların belediye başkanına düşüncelerini bildirmelerini sağlamak için İzmit Belediyesi bürolarının her katına bir mektup kutusu yerleştirilmiştir. 
- Çocuk Haklarını Öğrenelim: Çocukların demokrasi hakkındaki fikirlerini dinlemek için bir etkinlik yapılmıştır. Bu toplantı sırasında çocuklar için bir resim yapma etkinliği gerçekleştirilmiştir ve demokrasi hakkında konuşulmuştur.

- Bisiklet Turu: Şehrin sakinlerini Avrupa Yerel Demokrasi Haftası hakkında bilgilendirmek için bir bisiklet turu düzenlenmiştir.

- Çok Kültürlü Etkinlik: Farklı ülkelerden gelen yabanc1 ülke gençlerine Belediye bünyesinde Avrupa Yerel Demokrasi Haftası tanıtılmıştır.

Kadıköy Belediyesi: İstanbul'un bir ilçesi olan Kadıköy, 12 Yıldızlı Şehir statüsünü 2017 yılında almıştır. 2019 yılında bu statüsünü korumak için 2018 yılında şu etkinlikleri gerçekleştirmiştir (Avrupa Konseyi, 20180̈);

- Kadıköy Tiyatro Festivali: Yerel demokrasiyi güçlendirmek ve vatandaş katılımını arttırmak için ilçede tiyatro festivali düzenlenmiştir. Festivalde 2018 yılının teması olan çocuk ve gençlikle ilgili gösterilere de yer verilmiştir. Kadıköy Tiyatro Festivali kapsamında, çocuklara ve gençlere yönelik olarak Kukla Oyun Atölyesi ve diğer gösteriler düzenlenmiştir.

Kahramankazan Belediyesi: Ankara'nın bir ilçesi konumunda bulunan Kahramankazan, ilk olarak 12 Yıldızlı Şehir unvanını 2017 yılında almıştır. Unvanını 2019 yılında tekrar korumak için 2018 yılında şu etkinlikleri gerçekleştirmiş̧tir (Avrupa Konseyi, 2018p);

- Kahramankazan Gençlik Konseyi ile Buluşma: Belediye Başkanı gençlik meclisi ile bir araya gelerek haftanın önemine dair konuşma gerçekleştirmiştir.

- Gençlik Konseyi ile "KíTABÜS" Projesi: Belediyenin atıl durumdaki bir otobüsünün yenilenmesiyle daha öncesinden oluşturulmuş olan gezici kütüphane, ilgili hafta kapsamında da kullanılmıştır.

Karşıyaka Belediyesi: İzmir'in ilçesi olan Karşıyaka, ilk 12 Yıldızlı Şehir statüsünü 2015 yılında almıştır. Unvanını 2019 yılında tekrar korumak için 2018 yılında şu etkinlikleri gerçekleştirmiştir (Avrupa Konseyi, 2018r);

- Saygı Müzesi: Türkiye tarihinden önemli dönemleri vurgulayan bir şehir müzesi Karşıyaka Belediyesi tarafından açılmıştır.

- Aktif Vatandaşlık: Karşıyaka'da yaşayan tüm vatandaşların karar alma sürecine daha aktif katılımını sağlamak için Aktif Vatandaşlık Projesi başlatılmıştır. Dünyada yedi şehri (Karşıyaka dâhil) kapsayan "Küresel Aktif Şehir" çalışmaları kapsamında, projeye 500 'den fazla gönüllü vatandaş katılmıştır.

- Engelliler İçin Geçici Rekreasyon Merkezi: Karşıyaka Belediyesi tarafindan hayata geçirilen engelli merkezi ile engellilerin yakınları belirli saatlerde bakmakla yükümlü oldukları yakınlarını bu merkeze bırakabilmekte ve kendi başlarına zaman geçirebilmektedirler. Engelli bireyler, güvenli ve modern bir ortamda sosyalleşme firsatı bulmaktadırlar.

- Avrupa Yerel Demokrasi Haftası Öncesi Hazırlık Çalışmaları: Belediye meclisinde görüşülen ve kabul edilen uygulama kapsamında haftanın önemini vurgulamak ve daha kurumsal şekilde çalışmalar gerçekleştirmek için bayraklar, afişler, tişörtler, masa bayrakları ve posterler hazırlanmıştır.

Keçiören Belediyesi: Ankara'nın ilçesi olan Keçiören de 12 Yıldızlı Şehir statüsüne sahiptir. Fakat Avrupa Konseyi'nin veya Keçiören Belediyesi'nin internet sitelerinde belediyenin bu yöndeki çalışmalarına ilişkin bir bilgilendirme bulunmamaktadır. Sadece ilgili belediyenin bu statüye sahip olduğu Avrupa Konseyi'nin internet sitesinde belirtilmektedir (Avrupa Konseyi, 2018s). 
Lüleburgaz Belediyesi: Kırklareli'nin ilçesi konumunda bulunan Lüleburgaz 2014 yılından itibaren her yıl 12 Yıldızlı Şehir unvanını korumaktadır. Statüsünü 2019 yılında tekrar korumak için 2018 yılında şu etkinlikleri gerçekleştirmiştir (Avrupa Konseyi, 2018ş);

- Fotoğraf Sergisi "Kaos": Sanatın demokrasiyi güçlendirdiğini beyan eden Lüleburgaz Belediyesi, fotoğrafları yerel demokrasiye katkıda bulunan bir sanatçının çizim ve fotoğraf sergisini açmıştır.

- Girişimcilik Ĕgitimi: KOSGEB, Trakya Kalkınma Ajans1 ve Lüleburgaz Belediyesi işbirliğinde, Lüleburgaz Yıldızları Kadın Akademisi'nde (LYKA) girişimcileri desteklemek ve geliştirmek amacıyla uygulamalı girişimcilik eğitimi verilmiştir.

- Klasik Müzik Konseri: Avrupa Yerel Demokrasi Haftas1 kapsamında Trakya Oda Orkestrası tarafından bir klasik müzik konseri verilmiştir.

- Bisiklet Festivali: Avrupa Yerel Demokrasi Haftas1 kapsamında bisiklet festivali gerçekleştirilmiştir.

- "2019 Atatürk'ü Anlamak ve Gençlik Yılı" Çalıştayı: Lüleburgaz Belediyesi 2019 yılını "Atatürk'ü Anlamak ve Gençlik Yılı " ilan etmiştir. Tema y1lı hakkında gençlerin dâhil olduğu bir atölye çalışması düzenlenmiştir.

- "Kadın Krallı̆̆ı" Tiyatrosu: Avrupa Yerel Demokrasi Haftası'nda, Bulgar tiyatro grubu tarafından "Kadın Krallığı" isimli bir tiyatro gösterilmiştir. Böylece iki kültür arasında bir etkileşim sağlanması hedeflenmiştir.

- Gençler İçin Bilgilendirme Toplantısı: Lüleburgaz Belediyesi İnsan Kaynakları Departman Müdürlüğü tarafından, eğitim için şehre gelen yeni öğrenciler şehir hayatı hakkında bilgilendirilmiştir.

Kırklareli Belediyesi: Daha öncesinden de 12 Yıldızlı Şehir unvanını almış olan Kırklareli Belediyesi, unvanını 2019 yılında tekrar korumak için 2018 yılında şu etkinlikleri gerçekleştirmiştir (Avrupa Konseyi, 2018t);

- Belediye Başkanının Okul Ziyareti: Belediye başkanı İstiklal Ortaokulu'nu ziyaret etmiş ve çocukları demokrasi hakkında bilgilendirmiştir.

- Çocuk Fuarı: Avrupa Yerel Demokrasi Haftası kapsamında öğrencilerle bir Çocuk Fuarı düzenlenmiştir.

- "Mutlu Makas" Tiyatrosu: İlgili hafta kapsamında çocuklar için bir tiyatro düzenlenmiştir.

- Öğrencilerin Belediye Başkanını Ziyareti: Belediye başkanı kendisini ziyaret eden öğrencileri demokrasi konusunda bilgilendirmiştir.

- Engelliler İçin Dans Gecesi: Engelli vatandaşlar için bir dans gecesi organize edilmiştir.

- Makedonya Folklor Grubu: Kardeş kent Makedonya'dan çocuk folklor grubu gelerek etkinlik düzenlemiştir.

- Erasmus Öğrencilerinin Ziyareti: Erasmus kapsaminda Endonozya'dan gelen öğrenciler belediye başkanını ziyaret etmişlerdir ve Başkan tarafından ilgili haftanın önemine uygun konuşma yapılmıştır.

- Sanat Söyleşisi: Sanatın demokrasi içerisindeki önemini vurgulamak için ilgili hafta kapsamında bir sanat söyleşisi gerçekleştirilmiştir.

- Avrupa'da ve Türkiye'de Yerel Demokrasi Söyleșisi: İlgili hafta kapsamında siyasi parti temsilcileri ve eski belediye başkanlarının katılımıyla yerel demokrasi üzerine halkla bir söyleşi gerçekleştirilmişti.

Rize Belediyesi: Karadeniz bölgesinin kenti olan Rize, 12 Yıldızlı Şehir statüsünü ilk olarak 2018 yılında almış olmakla birlikte, unvanını 2019 yılında tekrar korumak için 2018 y1lında şu etkinlikleri gerçekleştirmiştir (Avrupa Konseyi, 2018u); 
- Rize’de Avrupa Günleri: İlgili haftanın önemini vurgulamak için belediye başkanı muhtarlarla bir araya gelmiştir.

- Demokrasi ve Çevre Etkinliği: Çevre sorunlarını demokratik bir anlayışla çözmek için vatandaşla ve sivil toplum kuruluşlarıyla bir toplantı düzenlenmiştir.

- Şehriniz Için Projeler Üretin Uygulaması: Katılımcılık anlayışı etrafında kent sakinlerinin kentleri için projeler üretmesi ve bu projelerini bir sergide halka tanıtmaları sağlanmıştır.

- Gençlik Demokrasisi Etkinliği: Kentteki gençlerin demokrasi hakkındaki farkındalıklarını arttırmak için duvar boyama etkinliği düzenlenmiştir.

- Yerel Yönetişimde Öğrencilerin Katılımı Etkinliği: Öğrencilerin yerel yönetimlerle ilgili beklentilerini dile getirdikleri bir toplantı belediye başkanıyla birlikte gerçekleştirilmiştir.

Zeytinburnu Belediyesi: İstanbul'un bir ilçesi konumunda bulunan Zeytinburnu, daha öncesinden almış olduğu 12 Yıldızlı Şehir statüsünü 2019 yılında tekrar korumak için 2018 yılında şu etkinlikleri gerçekleştirmiştir (Avrupa Konseyi, 2018ü);

- Gençlik Forumu: Zeytinburnu Kız İmam Hatip Lisesi'nde göç, uyuşturucu bağımlılığı, bisiklete binme, temiz ulaşım ve gençlerin katılımcılığını tartışmak için bir forum düzenlenmiştir.

- Gençlerle Belediye Başkanının Buluşması: Zeytinburnu Belediye Meclisi Gençlik Meclisi, ilgili hafta münasebetinde belediye başkanıyla bir araya gelmiştir.

Maltepe Belediyesi: İstanbul'un ilçesi olan Maltepe daha öncesinden bu etkinlikte yer almamıştır ve dolayısıyla 12 Yıldızlı Şehir statüsü bulunmamaktadır. Belediye bu statüyü ilk defa 2019 yılında almak için 2018 yılında şu etkinlikleri gerçekleştirmiştir (Avrupa Konseyi, 2018v);

- Çocukların Park Adı Belirlemesi: Belediyeye ait 8 anaokulunda oy sandığ kurularak, yaklaşı 500 öğrenciden kendilerine sunulan önerilerden birisini seçmeleri istenmiştir.

- Çocuk Konseyi Toplantısı: Demokrasi etkinliği gerçekleştirmek için yaşları 312 arasında değişen 40 çocuk, çocuk konseyi etkinliğinde bir araya getirilmiştir.

- Çocuk Katılımcılığı Etkinliği: Belediye tarafından gerçekleştirilen çocuk tiyatrolarında, çocukların kendilerine sunulan alternatiflerden park ismi oylamaları sağlanmıştır. Böylece katılımcılık anlayışı çocuklara aktarılmaya çalışılmıştır.

- Çevrimiçi Oylama: Maltepe halkının parklarına isim verebilmesi için, internet üzerinden oylama yapılmıştır.

Sarıyer Belediyesi Kent Konseyi: İstanbul belediyesi olan Sarıer Belediyesi'nin daha öncesinden 12 Yıldızlı Şehir statüsü bulunmamaktadır. Belediyenin kent konseyi tarafından 2018 y1lında ilgili haftayla ilgili şu etkinlik gerçekleştirilmiştir (Avrupa Konseyi, 2018y);

- Türkiye'de Dördüncü Gençlik Internet Yönetissimi Forumu: İnternet üzerinden yönetişimin sağlanması adına 4'üncüsü gerçekleştirilen forum 2018 yılında Sarıer Belediyesi Kent Konseyi bünyesinde gerçekleştirilmiş̧ir.

Sarıyer Belediyesi: Sarıyer Belediyesi, kent konseyinden ayrı olarak kendisi de ilgili hafta kapsamında etkinlik gerçekleştirmiştir. Gerçekleştirdiği etkinlik şu şekildedir (Avrupa Konseyi, 2018z);

- Çocuk Hakları Festivali: Sarıyer Gençlik Eğitim Merkezi (SAGEM) tarafindan tiyatro, müzik ve dans gösterileriyle çocuklara yönelik çocuk hakları farkındalık etkinliği gerçekleştirilmiştir. 


\section{Sonuç}

Yönetişim ve yerel yönetişim kavramlarının önemi her geçen gün daha çok anlaşılmaktadır. $\mathrm{Bu}$ kavramları hayata geçirecek uygulamalar da sürekli geliştirilmektedir. Özellikle gelişmiş ve gelişmekte olan ülkelerin yönetişime önem verdikleri ve bunu geliştirmek için çaba içerisinde oldukları görülmektedir. Avrupa Konseyi bu uygulamalardan somut bir tanesini hayata geçirmiş durumdadır. Avrupa Yerel Demokrasi Haftası adı altında yerel yönetişimi geliştirmeyi hedefleyen bu etkinlik ile 12 Yıldızlı Şehir statüsü verilmektedir. $\mathrm{Bu}$ etkinliğe Türkiye'den belediyelerin iştirak ettikleri görülmektedir. Fakat ilgili etkinliğe il özel idarelerinin, köy idarelerinin, STK'ların ve diğer yerel yönetişim aktörlerinin katılım sağlamadıkları görülmektedir.

Türkiye'de bu statüyü daha önce almış belediyelerin, statülerini ellerinde tutmak için her yıl düzenli olarak ilgili etkinliğe tekrar katılım sağladıkları gözlemlenmektedir. Ayrıca ilk defa bu etkinliğe katılarak 12 Yıldızlı Şehir unvanı almaya çalışan belediyelerin olduğu da dikkat çekmektedir. Bu kapsamda Avrupa Konseyi tarafindan ortaya konulan bu uygulamanın her geçen gün Türkiye belediyeleri tarafından daha çok benimsendiği ve Türkiye'de yerel yönetişimin geliştirilmesinde bir farkındalık yarattı̆̆ 1 sonucuna varılabilmektedir. Fakat İçişleri Bakanlığ1 verilerine göre Türkiye'de 1399 belediye, 51 il özel idaresi ve 18.335 köy idaresi olduğu göz önüne alınırsa; bu etkinliğe katılımın henüz düşük seviyelerde olduğu söylenebilir. Türkiye genelinde yerel yönetişimi geliştirmek üzere İçişleri Bakanlığı, Çevre ve Şehircilik Bakanlığı, Yerel Yönetimler Genel Müdürlüğü, Türkiye Belediyeler Birliği, Türkiye Cumhuriyeti Vilayetler Birliği, yerel yönetim birlikleri, STK'lar ve diğer resmi ve gayri resmi kurumlar tarafından hem Avrupa Konseyi'nin bu Avrupa Yerel Demokrasi Haftası etkinliğinin duyurulması hem de Türkiye merkezli yeni etkinliklerin ortaya konulması faydalı olabilir.

\section{Kaynakça}

4982 sayılı Bilgi Edinme Hakk1 Kanunu, Kabul Tarihi: 9.10.2003. Resmi Gazete. Tarih: 24.10.2003. Say1: 25269.

5393 say1lı Belediye Kanunu. Kabul Tarihi: 3.7.2005, Resmi Gazete, Tarih: 13.7.2005, Say1: 25874.

Avrupa Konseyi (2018a). https://www.coe.int/en/web/good-governance/12-principles-and-eloge (Erişim tarihi: 24.12.2018).

Avrupa Konseyi (2018b). https://www.coe.int/en/web/about-us/who-we-are (Erişim tarihi: 24.12.2018).

Avrupa Konseyi (2018c). https://www.coe.int/en/web/portal/turkey (Erişim tarihi: 24.12.2018).

Avrupa Konseyi (2018ç). https://www.coe.int/en/web/congress/overview (Erişim tarihi: 24.12.2018).

Avrupa Konseyi (2018d). https://www.coe.int/en/web/congress/origins-and-history (Erişim tarihi: 24.12.2018).

Avrupa Konseyi (2018e). https://www.coe.int/en/web/congress/overview (Erişim tarihi: 24.12.2018).

Avrupa Konseyi (2018f). https://www.coe.int/en/web/conventions/full-list//conventions/treaty/122 (Erişim tarihi: 22.12.2018).

Avrupa Konseyi (2018g). https://www.coe.int/en/web/congress/european-charter-of-local-selfgovernment (Erişim tarihi: 22.12.2018).

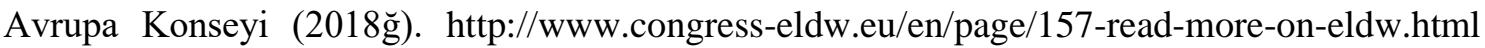
(Erişim tarihi: 23.12.2018). 
Avrupa Konseyi (2018h). http://www.congress-eldw.eu/en/page/159-thematic-ideas.html (Erişim tarihi: 23.12.2018).

Avrupa Konseyi (20181). http://www.congress-eldw.eu/en/page/122-12-star-cities.html (Erişim tarihi: 25.12.2018).

Avrupa Konseyi (2018i). http://sedl.alnetis.fr/en/ (Erişim tarihi: 27.12.2018).

Avrupa Konseyi (2018j). http://sedl.alnetis.fr/en/566-ahmetbey/ (Erişim tarihi: 26.12.2018).

Avrupa Konseyi (2018k). http://sedl.alnetis.fr/en/428-buyukcekmece/ (Erişim tarihi: 26.12.2018).

Avrupa Konseyi (20181). http://sedl.alnetis.fr/en/622-bagcilar-municipality/ (Erişim tarihi: 26.12.2018).

Avrupa Konseyi (2018m). http://sedl.alnetis.fr/en/505-be\%C5\%9Fikta\%C5\%9F/ (Erişim tarihi: 27.12.2018).

Avrupa Konseyi (2018n). http://sedl.alnetis.fr/en/559-edremit/ (Erişim tarihi: 27.12.2018).

Avrupa Konseyi (2018o). http://sedl.alnetis.fr/en/502-izmit-municipality/ (Erişim tarihi: 27.12.2018).

Avrupa Konseyi (2018ö). http://sedl.alnetis.fr/en/479-kadikoy/ (Erişim tarihi: 28.12.2018).

Avrupa Konseyi (2018p). http://sedl.alnetis.fr/en/512-kahramankazan/ (Erişim tarihi: 28.12.2018).

Avrupa Konseyi (2018r). http://sedl.alnetis.fr/en/413-karsiyaka/ (Erişim tarihi: 28.12.2018).

Avrupa Konseyi (2018s). http://sedl.alnetis.fr/en/627-kecioren-municipality/ (Erişim tarihi: 29.12.2018).

Avrupa Konseyi (2018ş). http://sedl.alnetis.fr/en/126-luleburgaz/ (Erişim tarihi: 29.12.2018).

Avrupa Konseyi (2018t). http://sedl.alnetis.fr/en/621-municipality-of-k\%C4\%B1rklareli/ (Erişim tarihi: 29.12.2018).

Avrupa Konseyi (2018u). http://sedl.alnetis.fr/en/571-rize/ (Erişim tarihi: 29.12.2018).

Avrupa Konseyi (2018ü). http://sedl.alnetis.fr/en/651-zeytinburnu-municipality/, (Erişim tarihi: 29.12.2018).

Avrupa Konseyi (2018v). http://sedl.alnetis.fr/en/658-maltepe-municipality/ (Erişim tarihi: 29.12.2018).

Avrupa Konseyi (2018y). http://sedl.alnetis.fr/en/660-sariyer-city-council/ (Erişim tarihi: 30.12.2018).

Avrupa Konseyi (2018z). http://sedl.alnetis.fr/en/661-sar\%C4\%B1yer-municipality/2-463festival-of-children-s-rights.html (Erişim tarihi: 30.12.2018).

Avrupa Toplulukları Komisyonu Raporu (2001). European Governance: A White Paper.

Boughton, J. ve Bradford, C. (2007). Global governance: New players, new rules, finance and development. Finance and Development, (12), 10-14.

Eryılmaz, B. (2013). Kamu yönetimi. 6. bask1, İstanbul: Umuttepe Yayınları.

Güven, A. ve Alan, Ç. (2018). Türkiye'de yerel yönetim yasaları çerçevesinde yönetişim anlayışının incelenmesi. Uluslararası Sosyal Araştırmalar Dergisi, 11(61), 840-847.

Işık, M. (2010). Avrupa Birliği’nin yönetişim anlayışı çerçevesinde Bilgi Edinme Kanunu'nun değerlendirilmesi. KMÜ Sosyal ve Ekonomik Araştırmalar Dergisi, 12(19), 39-49. 
İçişleri Bakanlığ1 (2018). https://www.e-icisleri.gov.tr/Anasayfa/MulkiIdariBolumleri.aspx (Erişim tarihi: 31.12.2018).

Kamuda İyi Yönetişim (2007). Dokuzuncu Kalkınma Planı Özel Ihtisas Raporu. http://www.sbb.gov.tr/wpcontent/uploads/2018/11/09_Kamuda\%C4\%B0yiY\%C3\%B6neti\%C5\%9Fimoik.pdf (Erişim tarihi: 27.12.2018)

Karasar, N. (2012). Bilimsel araştırma yöntemi. Ankara: Nobel Yayıncılık.

Kent Konseyi Yönetmeliği. Resmi Gazete, Tarih: 8.10.2006, Say1: 26313.

Özgökçeler, S. (2014). Yerel kalkınmada etkin bir kavram: Yerel yönetişim. “İş, Güç” Endüstri Illişkileri ve Insan Kaynakları Dergisi, 16(1), 67-82.

Sobacı, M. Z. (2007). Yönetişim kavramı ve Türkiye'de uygulanabilirliği üzerine değerlendirmeler. Yönetim Bilimleri Dergisi, 5(1), 219-235.

Türkiye Belediyeler Birliği (2018). http://www.tbb.gov.tr/basin-ve-yayin/haberler/20170719avrupa-yerel-demokrasi-haftasi-icin-cagri (Erişim tarihi: 25.12.2018).

United Nations Economic and Social Commission for Asia and the Pacific Raporu (2009). "What is Good Governance".

Yıldırım, Ö. K. (2018). Türkiye'de iyi yönetişim. Uluslararası Afro-Avrasya Araştırmaları Dergisi, (6), 273-289.

\section{ETİK ve BİLIMSEL İLKELER SORUMLULUK BEYANI}

$\mathrm{Bu}$ çalışmanın tüm hazırlanma süreçlerinde etik kurallara ve bilimsel atıf gösterme ilkelerine riayet edildiğini yazar(lar) beyan eder. Aksi bir durumun tespiti halinde Afyon Kocatepe Üniversitesi Sosyal Bilimler Dergisi'nin hiçbir sorumluluğu olmayıp, tüm sorumluluk makale yazarlarına aittir. 